\title{
Renewing the Case for Regionalism: EU Transnational Governance in an Era of Regulatory Nationalism
}

\author{
Diamond Ashiagbor*
}

\section{A. Introduction}

The EU faces a conundrum: The organization of economic activity remains transnational, whilst the turn to populism, nationalism, and even nativism, heightens the political shift to viewing the national level as the only legitimate site of regulation. After Brexit and in the era of Trump and resurgent nationalism, what are the prospects for the EU to (re)gain legitimacy as a source of transnational regulation?

The focus of this Article is on the (perceived) unresponsiveness of elite institutions, most notably the EU, to popular interests wary of globalization, from both the political left and right. The EU has been described as a "market without a state," with the concomitant problems of political legitimacy and democratic accountability which arise when market integration and economic governance take place at supranational level in the absence of a supranational polity. This rightly gives rise to concerns about the viability of democratic control over capitalism. The irony is, however, that the regionalism of the European Union is - or rather, has in the past been-an important institutional counterpoint to, and bulwark against, the worst effects of neoliberal globalization.

\section{B. Then: Embedding Capitalism Nationally_and Regionally}

It is clear that "economic law," in other words, law which "institutionalizes markets and provides for their functioning," 2 and which encompasses private economic ordering-of contracts, of corporations, of private property, of competition-as well as public ordering through social regulation - such as product safety, environmental law, labor and social welfare law-has increasingly been relocated away from the state.

Historically, liberal market economies, such as those of the states of the EU, were able to establish social cohesion and solidarity, and to govern or embed capitalism, for example, in order to enact labor standards. ${ }^{3}$ Labor law scholarship has traditionally focused on the role of the state and its capacity, or otherwise, to regulate a territorially bounded market to socialize economic risk and uncertainty. But capital and the sphere of economic interaction are increasingly de-territorialized. Therefore, we also need to ask whether, from the perspective of labor regulation, economic activity -in particular that which crosses national borders - can any longer be contained within or constrained by state regulation, and the attendant role of regulation on the regional or transnational plane. Alain Supiot describes the social state as merely a mode for the realization of the objective of

\footnotetext{
*Professor of Law in Kent Law School, University of Kent; d.ashiagbor@kent.ac.uk.

${ }^{1}$ Christian Joerges, The Market Without a State? States Without Markets? Two Essays on the Law of the European Economy, EUI LAW WORKING PAPER (1996).

${ }^{2} I d$.

${ }^{3}$ See discussion infra note 10 .
}

(C) The Author(s) 2020. Published by Cambridge University Press on behalf of the German Law Journal. This is an Open Access article, distributed under the terms of the Creative Commons Attribution-NonCommercial-NoDerivatives licence (http://creativecommons.org/ licenses/by-nc-nd/4.0/), which permits non-commercial re-use, distribution, and reproduction in any medium, provided the original work is unaltered and is properly cited. The written permission of Cambridge University Press must be obtained for commercial re-use or in order to create a derivative work. 
social solidarity. He talks of conceiving "an international legal order that will prohibit the use of open borders to escape the duties of solidarity inherent in the recognition of economic and social rights." 4

This state capacity was considerably bolstered by being part of a regional integration project, an international legal order, namely the European Union. One might even argue that a significant source of legitimacy for EU action was precisely its ability to institutionalize markets which are no longer territorially bound; to embed markets at the regional level, and thus enable national, democratic control over capitalism.

This might not have been the original understanding of the EEC project. Although ordoliberal theory is by no means the only conception of the economy to inform European integration, it has shaped legal discourse, in particular, in its view that the original treaties entrenched a particular version of the free market economic constitution. ${ }^{5}$ The German ordoliberal conception of the competitive market order argues that the economy functions best when self-coordination of economic actors through market transactions or competition is left unimpeded by law. Whilst it did require a coherent legal framework to guarantee individual freedoms and the economic process, ordoliberal thinkers perceived the original Treaty of Rome, and the creation of supranational European integration project, as "taming" the nation state in order to make the region a better home for free-moving capital. ${ }^{6}$ The Treaty of Rome is therefore idealized by ordoliberals as the paradigm economic constitution in that it appeared to concern exclusively economic rights; those elements of the Treaty, as subsequently amended, which go beyond pure market integration are considered as imperfections. Yet, it is precisely those imperfections that enable the EU regionalism project to operate to embed capitalism. As Floris de Witte notes, contrary to the ordoliberal paradigm, the aim of integration in the form of completion of the internal market was not to free the economy from political constraints, "but rather to support and insulate the capacity to constrain the economy at the national level, where sufficiently strong political structures existed."7

Thus, whilst there are tensions between nationalism and the transnational, it is not necessarily the case that in an era of multi-level governance, the regional or transnational is inherently about dispossessing, disembedding, or weakening the social for the sake of the market. ${ }^{8}$

Nevertheless, is the postwar marriage of democracy and capitalism, as Wolfgang Streeck has suggested, ${ }^{9}$ at an end? I would answer this question with the observation that democracy is not compatible with market fundamentalism, but that in the global North in the postwar era, it was, in large part, compatible with an "embedded liberal" bargain. As Polanyi observed, "[t]he road to a free market was opened and kept open by an enormous increase in continuous, centrally organized and controlled interventionism;" laissez faire was planned. ${ }^{10}$ Whether within liberal market economies or coordinated market economies, there was an acceptance that capitalism or trade liberalization had to be embedded in society and hence in democracy and some version of collectivism. ${ }^{11}$

Where I disagree with Streeck is in the role he attributes to supranational, regional bodies such as the EU: Doubting the possibility of the EU project being constitutionalized, or the scope for a

\footnotetext{
${ }^{4}$ Alain Supiot, Grandeur and Misery of the Social State, 82 NEw LefT REv. 99 (2013).

${ }^{5}$ See Wolf Sauter, The Economic Constitution of the European Union, 4 Colum. J. EUR. L. 27 (1998).

${ }^{6}$ See Quinn Slobodian, Globalists: The End of Empire and the Birth of Neoliberalism (2018); Diamond Ashiagbor, Collective Labor Rights and the European Social Model, 3 L. \& ETHICs HuM. RTs. 222 (2009); Wolfgang Streeck, Fighting the State, 50 Dev. \& CHANGE 836 (2019) (reviewing Quinn Slobodian's Globalists).

${ }^{7}$ Floris de Witte, The Architecture of the EU's Social Market Economy, in RESEARCH HANDBOOK ON THE LAW OF THE EU'S INTERNAL MARKET (Panos Koutrakos \& Jukka Snell eds., 2017).

${ }^{8}$ Article 3(3) of the Treaty on European Union (TEU), as inserted by the Lisbon Treaty, 2009, commits the Union to creating "a highly competitive social market economy." But see below.

${ }^{9}$ Wolfgang Streeck, How Will Capitalism End?: Essays on a Failing System (2016).

${ }^{10}$ Karl Polanyi, The Great Transformation 147, 156 (1944).

${ }^{11}$ John Gerard Ruggie, International Regimes, Transactions, and Change: Embedded Liberalism in the Postwar Economic Order, 36 INT'L ORG. 379 (1982).
} 
supranational democracy to emerge from international capitalism. ${ }^{12}$ Nevertheless, this rejection of the region as a legitimate site of regulation ignores the history of how for industrialized economies of the global North, including those in Europe, the protection of society from the market occurred due to the evolution in the protective capacities of individual states, but crucially also the evolution in the protective capacities of the region.

\section{Now: The EU's Role in Hastening the Disembedding of Capitalism}

The period during which the EU integration project and, in particular, its social policy, served as a bulwark to the ability of member states to embed the market, has come to an abrupt end-ironically, at the same time that the Treaties commit the Union to creating "a highly competitive social market economy." ${ }^{\prime 3}$ The response of EU institutions to the sovereign debt crisis has led to a weakening of social and labor rights, and an erosion of social solidarity, which has contributed to the intensification of populist tendencies. ${ }^{14}$ Long before this current crisis, the Lisbon Strategy, the Employment Strategy, and the "open method of coordination" (OMC) ${ }^{15}$ can be said to have undermined the very social objectives which might ameliorate the operation of markets. The background values and norms of EU economic policy in general, and the Stability and Growth Pact and Economic and Monetary Union in particular, ${ }^{16}$ constrain national employment and economic policy and necessitate strict fiscal discipline, restrictions on public expenditure, modernization of social protection systems, and structural reforms to make labor markets economically responsive and enhance their competitiveness. As van Apeldoorn observes, such asymmetric multilevel governance ensures that socio-economic policy-making is structurally biased towards policies of neoliberal restructuring. ${ }^{17}$

Social objectives and governance have lost way to, and been subsumed within, the broader economic policy governance of the European Semester: An annual cycle of coordination and surveillance of the EU's economic policies, involving detailed scrutiny of Member States' plans for macroeconomic, budgetary, and structural reforms. ${ }^{18}$ An optimistic reading is that economic policy coordination has been "socialized" with social policy objectives-for example, poverty and social inclusion-increasingly being included in the-relatively "hard law"-institutional and

\footnotetext{
${ }^{12}$ STREECK, supra note 9, at 198.

${ }^{13}$ See Gareth Dale \& Nadine El-Enany, The Limits to Social Europe: EU Law and the Ordoliberal Agenda, 14 GERMAN L.J. 613 (2013). Where I differ from the assessment offered by Dale and El-Enany is in the extent to which ordoliberalism can be said to be dominant in the middle period of European integration. I would, though, agree that since the Lisbon Treaty-and, before that, the Lisbon Strategy in relation to employment and economic policy-neoliberalism and ordoliberalism have been in the ascendancy.

${ }^{14}$ Claire Kilpatrick, The Displacement of Social Europe: A Productive Lens of Inquiry, 14 Eur. Const. L. REV. 62 (2018); see also Claire Kilpatrick, Abnormal Legal Sources and Institutional Actions in the EU Sovereign Debt Crisis, in LEGAL ACTS IN THE EU: Challenges and Transformation 70 (Marise Cremona \& Claire Kilpatrick eds., 2018).

${ }^{15}$ The European Employment Strategy was launched in 1997 with the goal of a high level of employment, to be achieved through what became known as the open method of coordination: An annual, iterative procedure using soft law to improve the efficiency of labor markets through the setting of guidelines, benchmarks, and indicators at the European level, their translation into national policies, and the periodic monitoring of such implementation, mostly by means of peer review. Presidency Conclusions, Lisbon European Council (Mar. 23-24, 2000), https://www.europarl.europa.eu/summits/ lis1_en.htm.

${ }^{16}$ Enforced through multilateral surveillance and the excessive deficit procedure-the " 3 percent budget deficit rule."

${ }^{17}$ Bastiaan van Apeldoorn, The Contradictions of "Embedded Neoliberalism" and Europe's Multilevel Legitimacy Crisis: The European Project and Its Limits, in CONTRADICTIONS AND LIMITS OF NEOLIBERAL EUROPEAN GOVERNANCE: FROM LISBON TO LisBon (Bastiaan van Apeldoorn, Jan Drahokoupil \& Laura Horn eds., 2008).

${ }^{18}$ The priority of the European Semester, introduced in 2010, is fiscal stability and debt reduction which, it is argued, will "create the conditions for more and better jobs, greater social fairness, and better living standards for Europeans." European Commission Press Release IP/18/6462, European Semester Autumn Package: Bolstering Inclusive and Sustainable Growth (Nov. 21, 2018). See Kilpatrick, supra note 14; Mark Dawson, New Governance and the Displacement of Social Europe: The Case of the European Semester, 14 Eur. Const. L. REV. 191 (2018).
} 
policy framework of the European Semester. ${ }^{19}$ A more convincing reading, however, is that EU social policy lacks autonomy and is increasingly contained within an institutional framework, which requires such policy to be "growth-friendly" and to ensure fiscal stability. Rather than shielding workers - and others - from the market, the aim of EU social policy becomes to facilitate their operation in the market whilst also facilitating market integration. ${ }^{20}$

And the role of the EU in exacerbating such disembedding - in urging the retrenchment of national welfare states, in downgrading the redistributive aspirations of social policy, and in the general incursions against labor law and labor market institutions-ensures it is a strong target for anti-globalization sentiment.

\section{Next: A Category Error — Market Fundamentalism Turned Inwards}

The resistance from countries in the global South to forms of transnational regulation, for example of the sort imposed by structural adjustment, is now, through curious reversal, being mirrored by opposition to transnational regulation in countries in the global North. The slogan of the Leave campaign in the UK, advocating the UK's exit from the European Union, was "take back control;" that resonated with the claim of Donald Trump to "Make America Great Again" and to place "America First." Both sets of slogans imply a nostalgia, or rather a fantasy, for a lost state: One which is fully sovereign, unfettered by international or supranational obligations, freed from the constraints of a liberalized global trading regime, whose rules it had been responsible for crafting, and-most significantly-almost entirely free from migrants.

One of the examples of the unease being expressed by observers in the global North is in relation to mega-regional trade agreements, such as the now-defunct Transatlantic Trade and Investment Partnership (TTIP). ${ }^{21}$ TTIP, if ratified, would have imposed an investment law regime stripping these sovereign states of their policy space and regulatory autonomy, and doing so in a manner reminiscent of the experience of states of the global South, which witnessed investment treaty law and bilateral agreements as a continuation of predatory capitalism and neocolonialism in a supposed postcolonial era. There is a similar symmetry between the deregulatory reform policies being imposed on those EU member states receiving financial support from the Troika of the European Commission, European Central Bank and IMF, and the effect of structural adjustment programs implemented by the IMF and the World Bank on markets in developing states from the 1970s onwards. In both cases-neocolonial trade agreements compared with the new wave of "mega-regional" agreements and structural adjustment compared with austerity as a response to sovereign debt crisis- the techniques of neoliberal governance are following a pattern first trialed on the global South. European states are experiencing this as a category error, in part because they have not been on the receiving end of such policies, but most importantly because it is the rest of the world which has been subject to the economic power of their corporations and investment law regimes.

This market fundamentalism is now turned inwards on the EU states themselves. Whether we agree with Hien and Joerges that Anglo-American neoliberalism rather than German ordoliberalism has been in the ideational driver's seat of EU economic policy since the $1980 \mathrm{~s},{ }^{22}$ it is clear

\footnotetext{
${ }^{19}$ Jonathan Zeitlin \& Bart Vanhercke, Economic Governance in Europe 2020: Socialising the European Semester Against the Odds?, in Social Policy in the European Unions: State of Play 65 (David Natali \& Bart Vanhercke eds., 2015).

${ }^{20}$ As I've argued elsewhere, the Lisbon Strategy and the "open method of coordination" essentially ushered in or reinforced a version of EU social policy which is predicated on equalizing the marketability and employability of individuals in the market, rather than protecting them from the market. Diamond AshiagBor, The European EMPloyment Strategy: LABOuR Market Regulation and New Governance 6, 71 (2005); Dawson, supra note 18, at 193.

${ }^{21}$ A 2019 Council Decision states that the negotiating directives for the TTIP are obsolete and no longer relevant. Council Decision 6052/19 of Apr. 9, 2019 Authorising the Opening of Negotiations with the United States of America for an Agreement on the Elimination of Tariffs for Industrial Goods.

${ }^{22}$ Josef Hien \& Christian Joerges, Dead Man Walking? Current European Interest in the Ordoliberal Tradition, 24 EUR. L. J. 142 (2018).
} 
that the original imperatives behind Europe's economic constitution have returned with a vengeance. A major challenge for the 2020s is whether the EU can finally address the question of what it means to construct a polity that proceeds from economic rationality to social justice. At certain points in its evolution, it has been able to adopt alternative visions of the economy, which do allow for the possibility of market-correcting intervention. Nonetheless, on current form-illustrated by neoliberal responses to the present crises-it is difficult to envisage how the EU can succeed in institutionalizing a labor or social constitution (Arbeitsverfassung) to hold in check or counter the emergence of an economic constitution (Wirtschaftsverfassung). ${ }^{23}$

Streeck argues that democracy can be made compatible with contemporary capitalism, but only by safeguarding or shielding the redistributive potential of democratic politics from the worse aspects of free markets, from financialized disembedded capitalism. The surrendering of state sovereignty to global finance capital and the withdrawal of the EU from its sometimes role in supporting such state capacity certainly makes it much more difficult to create or maintain democratically determined collective values and institutions.

\footnotetext{
${ }^{23}$ The idea of the economic constitution (Wirtschaftsverfassung) can be understood in opposition to the social or labor constitution (Arbeitsverfassung) tradition that Hugo Sinzheimer and others had identified during the short years of the Weimar Republic. See Ruth Dukes, The Economic Sociology of Labour Law 46 J.L. \& Soc'Y 396 (2019).
}

Cite this article: Ashiagbor D (2020). Renewing the Case for Regionalism: EU Transnational Governance in an Era of Regulatory Nationalism. German Law Journal 21, 41-45. https://doi.org/10.1017/glj.2019.93 